\title{
Metaphor of 'Adaptation': A Metaphoric Rhetorical criticism on Aminuddin Baki's Torch Movement Speech 3
}

\author{
Dil Froz Jan Sayed Halem Shah ${ }^{1 *}$, Abdul Mua'ti @ Zamri bin Ahmad, PhD ${ }^{2}$, Hamisah \\ Zaharah Hassan, $P h D^{2}$, Rosya Izyanie Shamshudeen, $P h D^{2}$ and Faridah Ibrahim, $P h D^{2}$ \\ ${ }^{1}$ Faculty of Arts, Communication and Education, Infrastructure University Kuala Lumpur, \\ ${ }^{2}$ Faculty of Modern languages and Communication, University Putra Malaysia
}

\begin{abstract}
This paper looks at the Aminuddin Baki's Torch Movement Speech 3 (Ceramah Gerakan Obor 3). It's is to identify the type of metaphors used and how the metaphors are conveyed in the Torch Movement Speech 3 on 'Adaptation' of the Malays. The study hopes to identify the direction of the 'Adaptation' metaphor which is liken banana tree and its offsprings. Many studies have been carried out on the biographical portion of Aminuddin Baki but none on all his Torch Movement Speeches that he had made on the progression and development of the Malays. A qualitative method was used through a rhetorical analysis. A Neo-Aristotelian Criticism is used in the analysis of speech of which this study demonstrates the relevance in the application of ancient Malay metaphors in the modern day communication interaction among the Malays.
\end{abstract}

\section{Introduction}

Aminuddin Baki was a rhetor and committed to seeing the advancement of Malaysians by communicating educational advancement. He made considerable contributions to the revolution of education in Malaysia by giving speeches on how the nation can pace proactively into the future without falling behind. He was aspired to see his country prospers whereby the natives would be given the respect and equal rights that they deserve.

\subsection{Research Context}

Aminuddin Baki was a revolutionary rhetor who tried to impart change into the phlegmatic Malay culture. He disagreed with most of the standpoint maintained by the Malay heritage [5] with regard to progress. The rhetor was capable of being disagreeable to certain deeply rooted cultural issues without inciting rebellion among the audience [3]. A rhetorical methodology was carefully designed by the rhetor to achieve a particular communicational goal which is yet to be analyzed within the paradigms of contemporary theories. Metaphors ensure a familiar but forceful connection to be made between the listeners and the rhetoric message. It requires a soigne concoction however, since the wrong metaphor would fail to

\footnotetext{
* Corresponding author: dilfrozjan@iukl.edu.my
} 
invoke the desired response from the audience, and consequently falter in creating a singular impact on the community of interest [22]. It is therefore highly critical for the purpose of this research to solve the aforementioned problem.

\title{
1.2 Research Objectives
}

This research focuses solely on the use of metaphors in attaining the desired response from the audience. This is congruent with the level of education possessed by the audience at that time. This research aims to complete the following objectives:

a. To identify the metaphors employed within a certain context

b To determine the structure of the metaphor within the certain context of the speech

\section{Literature Review}

Metaphor is a form of figurative speech that enables indirect communication to take place. Metaphor imparts meaning by adopting external concepts. As such, it requires a flexible interpretation of dual ideas. This is examined under the Contemporary Theory of Metaphor [21], which deals with the prospect of employing metaphors in mapping, reasoning and problem solving.

\subsection{Rhetoric}

If speech is inextricably linked to a purpose, then rhetoric is the art of communicating this purpose [23].

\subsection{Metaphor}

Development, as the term suggests, would challenge the community to leave their comfort zone into a new horizon. In doing so, it is vital for them to adapt to change. This can be a perilous process. Adaptation [31], requires the community to be flexible to the dynamic nature of the environment.

\author{
Kalaulah usaha (penyesuaian) ini gagal, akan berbuahlah pisang dua \\ kali [2] \\ If this attempt (for adaptation) fails, then the banana would bear fruit twice
}

\subsection{Speech}

The speeches given by leaders of the largest organization in America was studied by [5], and three general corporate strategies were introduced to eliminate problems. They were - influencing government policy, education on economic for the public and increasing social responsibility of the business part.

\section{Methodology}

This is a content analysis research that uses the neo-Aristotelian criticism. Metaphoric criticism is an approach that emphasizes mostly on a very specific strategy implemented within rhetoric. By employing metaphors, the meaning attached to a concept can be 
dynamically changed [26]. The ability of metaphor to alter the perception of a message makes it very alluring $[6,3]$ and compel the audience to be more receptive. This study analyses the metaphoric content of Aminuddin Baki's Torch Movement Speech 3 which emphasizes on 'Adaptation.'

\section{Analysis and Discussion}

Metaphorical meaning is to combine the meaning of both tenor and vehicle to derive the mapping that exists between the two [34]. Both meanings must complement each other for the metaphor to work. Once the meaning is clarified, its impact is probed more closely. Given the unavailability of audience and exigence from 1960s, only the desired impact of the rhetorician is scrutinized. Metaphors detected in Baki's speech are interpreted based on several themes.

\subsection{Kalaulah usaha (penyesuaian ini gagal, akan berbuahlah pisang dua kali [2] If this attempt (for adaption) fails, then the banana would bear fruit twice}

Since the obstacle varies with time, so must the community. Being static is a dangerous alternative. The force of nature [15] often displays the extinction of a species that does not progress with its environment.

Deciding the course of action in responding to change is a serious issue that needs to be addressed [8]. Without the right supervision, adaptation can disintegrate the community. People can make the wrong decisions and act poorly in the face of calamity.

\subsection{Metaphorical Element}

Banana is a tropical fruit in Malaysia coming from the banana tree of genus Musa. It is usually yellowish in color. The structure of the fruit is long and curved. Its content is soft and slightly mellow in taste. The fruits of the banana exist in a cluster and hang and the top of the banana tree. Monocarpic [20]. By nature, the banana tree bears fruit only once in its entire lifetime. Before passing, the banana tree would naturally propagate new offspring at the bottom of the tree. The life cycle of a banana tree is conceived simplistically as a five state process. It begins with the propagation of seedling, which will develop into an offspring. As time passes, the offspring grows into a banana tree. The tree experiences fruiting where it produces the banana. Ineluctably, the final state is the death or demise of the tree. A notable trait of the banana tree is its fruiting repertoire.

The banana tree metaphor ideates the construct of mistake in a rather queer manner. Strange in the sense that it paints the fruiting process of a tree in a deplorable limelight, when it should have been a positive one [35].

Now, it is compelling to have a closer look at mistake [13] before bridging it to the metaphor in question. To note, mistake is defined as the course of action which causes a negative effect as compared to the intended goal.

The banana tree metaphor ideates the construct of mistake in a rather queer manner. Strange in the sense that it paints the fruiting process of a tree in a deplorable limelight, when it should have been a positive one [35].

In this respect, the construct of mistake [29] can be decomposed into four main components - original intention, actual occurrence, destructive action and unforeseen penalty. The original intention is the true motivation behind the act of the individual. It is usually tied to a course of action.

A possible explanation can be found by the inability to make the right estimation in 
adapting [7]. For the sake of argument, assume that a general guideline has been established with regard to the acceptable amount of parasite to be sprayed on the crops. Without loss of generality, assume further that for one acre of land, two liters of pesticide is recommended.

Unfortunately, the logic behind the safety of pesticide may not be mathematically based [27]. There might be other factors, such as accumulation of pesticide or environmental ramification. Here, the mistake is caused by the failure to adapt to the change. The capacity to adapt to change is essential in making the right decision and avoiding mistakes.

\subsection{Metaphorical Meaning}

The metaphor connects the banana tree to the action performed by an individual. It is a truism that a banana tree grows with time. A similar conception can be said on a series of actions that mount through time. When more actions are deployed on a particular endeavor, the amplitude of strain is greater [16].

Ironically, the metaphor associates the bearing of a fruit as an instigation of mistake. This is quite paradoxical, given the fact that the fruit of a tree that can be eaten, should distinctly be perceived as the emergence of good tiding, instead of an ominous one.

From the error making point of view, it can be inferred from this portrayal that it is forgivable to commit a mistake for the first time [28], as it would serve as an initial orientation to the learning experience.

In retrospect, the metaphor indirectly conveys a subtle lesson that failure is a natural phenomenon in life [1]. No one is free from fault.

\subsection{Metaphorical Impact}

The desired impact of using the banana tree metaphor is to promote the importance of learning from past mistake such that it will not recur. This can be quite challenging, given the fact that a fierce competition always exists between right and wrong, from the way a person defines his own values [11].

Learning from a past mistake can happen in two ways. The most common is to learn from one's own experience [4] in order to change.

Previously, a detailed analysis is given on the metaphor that represents mistake as the second fruiting of the banana tree. For comparison it is contrasted with another metaphor that insinuates 'mistake as music.' Logically, this too is a quaint metaphor, given that music is said to be therapeutic in the present time [10].

Face the music

Mistake is like music

If this attempt (for adaptation) fails, then the banana would bear fruit twice MISTAKE IS LIKE THE SECOND FRUITING OF THE BANANA TREE

Understanding the music metaphor requires a slight explanation to its rationale. It is hypothesized that the metaphor had originated from the suspense experienced by a performer before appearing on stage [30]. As the curtain is lifted and music is being played for the sake of introducing the play, the performer must face his fears and the audience.

In term of its goal, the music metaphor encourages the audience to embrace accountability [32] in dealing with the consequence of a mistake. 


\section{Conclusion}

For the Malays to be successful in any vocation, they must learn to adapt to the ever changing needs and challenges of the environment [2]. In doing so, learning from their past mistakes, as well as the mistakes of others, is one of the most critical requirements of success. An individual can only be progressive if he can honestly look at himself in the mirror and ascertain his own weakness without excuse.

Having the right set of beliefs to succeed, or self-efficacy as experts would say, is a cultural trait to a certain extent. Certain communities are highly deterministic. They relate nearly all forms of success to humanism i.e. how we act as whole. The Malay community may not share the same zest for humanism. With the influence of Islam, they are taught to be humble in their attempt for success.

A common saying among them is "Effort must be made but the final decision comes from God ..." Sadly, certain extremists propagate a false interpretation of this principle. They promote the belief that every failure is fated and in doing so, discounts the importance of making effort entirely.

This is a portion of doctoral research work undertaken by Dil Froz Jan at Universiti Putra Malaysia. The other three metaphors were also discussed in previous papers and journals. The methodologies used are similar to the previous papers.

\section{References}

1. E. Addessi, F. Bellagamba, A. Delfino, F. De Petrillo, V. Focaroli, L. Macchitella, V. Maggiorelli, B. Pace, G. Pecora, S. Rossi, A. Sbaffi, M. I. Tasselli, F. Paglieri. Cognition, Volume 130, Issue 3, March 2014, Pages 428-441. (2012)

2. Aminuddin Baki. "Cheramah 3 Siri Gerakan Obor" Radio Malaysia. (1964c)

3. Ibarretxe-Antunano, B.I (1999). Polysemy and Metaphor in Perception Verbs: A Cross Linguistic Study: PhD Thesis. University of Edinburgh, 1999.

4. J. Angouri, \& M. A. Locher. Journal of Pragmatics 44 (2012) 1549-1553. (2012)

5. Myers, R.J, \& Kessler, M S (1980). The Rhetorical Analysis of Business Speech: Unresolved Questions Journal of Business Communication, July 2010 47: pages $346-368$

6. S. Billett. Educational Research Review, Volume 12, June 2014, Pages 1-13. (2014)

7. R. Biria, A. Mohammadi. J Pragmatics 44 (2012) 1290-1302. (2012)

8. L. Cirillo. Heinz Werner and Developmental Science Path in Psychology 2005, pp 109-119. (2005)

9. S. Dekker. Appl Ergonomics, Volume 34, Issue 3, May 2003, Pages 233-238. (2003)

10. P. Gentle, \& T. N. Maraseni. "Climate change, poverty and livelihoods: adaptation practices by rural mountain communities in Nepal." (2012)

11. D. Fancourt, A. Ockelford, A. Belai, Brain, Behavior, and Immunity, Volume 36, February 2014, Pages 15-26. (2014)

12. V. V. Gouveia, T. L. Milfont, \& V. M. Guerra. "Functional theory of human values: Testing its content and structure hypotheses." (2014)

13. C. Harteis, J. Bauer, H. Gruber. International Journal of Educational Research, Volume 47, Issue 4, 2008, Pages 223-231. (2008)

14 M. M. Islam, S. Sallu, K. Hubacek, J. Paavola. Marine Policy, Volume 43, January 2014, Pages 208-216. (2014)

15. F. Kadri, S. Chaabane, C. Tahon. Simulation Modelling Practice and Theory, Volume 42, March 2014, Pages 32-52. (2014)

16. K. Kitajima, K. A. Carol. Ecology (jstor) 70 (4): 1102-1114. (1989) 
17. G. Lakoff. Ortony, A. (Ed.), Metaphor and thought (2nd ed.), Cambridge, UK: Cambridge University Press. (1993)

18. M. Marra. "Disagreeing without being disagreeable: Negotiating workplace." (2012)

19. E. Oishi. "Austin's Speech Act Theory and the Speech Situation." Esercizi Filosofici 1, 2006, pp. 1-14. (2006)

20. M. M. Rodriguez Marquez. "Patterns of Translation of Metaphor in Annual Reports" in American English and Mexican Spanish. PhD Thesis, University of Surrey, (2010)

21. A. Saini. New Scientist, Volume 204, Issue 2731, 21 October 2009, Pages 42-45. (2009)

22. R. Santagata. Linguistics and Education, Volume 15, Issues 1-2, spring 2004, Pages 141-164. (2004)

23. B. Scholnick, N. Massoud, A. Saunders. "Journal of Financial Stability, Volume 9, Issue 1, April 2013, Pages 26-37. (2013)

24. R. Studer, B. Danuser, H. Hildebrandt, M. Arial, P. Gomez. Journal of Psychosomatic Research, Volume 70, Issue 6, June 2011, Pages 557-564. (2011)

25. N. Suckall, E. Tompkins, L. Stringer. Applied Geography, Volume 46, January 2014, Pages 111-121. (2014)

26. P. E. Tetlock, F. M. Vieider, S. V. Patil, A. M. Grant. (2013)

27. R. Tourangeau, R. J. Sternberg. Cognition, Volume 11, Issue 3, May 1982, Pages 203-244. (1982)

28. L. W. I. Wairegi, P. J. A. van Asten, M. Tenywa, M. Bekunda. (Musa spp. AAA-EA). (2009) 